\title{
RESEARCH OF MEDICAL PRODUCTS PURCHASE MOTIVATION FACTORS
}

\author{
M. Kulumbekova \\ North Ossetian State University.Vladikavkaz, Russian Federation \\ science-almanac@mail.ru
}

\begin{abstract}
On the basis of quiz results of pharmaceutical production consumers of Vladikavkaz, the author formed the basic features of consumer behavior model at the region pharmaceutical market. Thus, the basic problems, connected with clients service and establishment contact with them turned to be:insufficiency of products knowledge from the position "characterisrics- advantage-benefit"; absence of behavior experience with dissatisfied customers;inefficiency to conduct express-analysis of conducted sale.However, under the conditions of pharmaceutical networks development in the region, from one side, and necessity of alternative pharmaceutical enterprises functioning, from the other, one should emphasize priority marketing tools for the specified forms of pharmaceutical retail. Herewith, the general, in our opinion is considered to be the using of "attract-function" technology, which consists of three basic components:service constituent - accessibility of curative assistance, quality guarantee, catalogue of provided services and etc.; aesthetical constituent pharmacy interior decoration, appearance of service personnel, design of offered goods for realization and etc.; ethical constituent - attitude to the customers and the experience to work with them. The main condition for the clients-oriented approach - necessity to develop and find balance between all three components of "attract-function".
\end{abstract}

Key words: consumer behavior, sales promotion, strong brend, loyalty program, preferences of Vladikavkaz pharmacy visitors.

In the result of generalization of Russian authors researches one can make a conclusion that the important factors of consumer behavior stimulation at pharmaceutical market are: pharmacy branding, loyalty programs, consulting assistance to clients of pharmacies and etc [1-5].The research results of medications consumers preferences of Vladikavkaz, confirming conclusions, received on the basis of theoretical sources research, are represented in the Table 1 . The table is composed by the author on the basis of quiz of 150 employees and students of North-Ossetian state university of K.L.Khetagurov.

Table 1

Preferences of pharmacies visitors of Vladikavkaz

\begin{tabular}{|l|l|l|l|l|}
\hline № & Importance criteria & Important & Unimportant & Sometimes \\
\hline 1 & Assortment policy & & & \\
\hline 1.1 & Large choice of medications & 57 & 4 & 3 \\
\hline 1.2 & Presence of infrequent medications & 33 & 10 & 21 \\
\hline 1.3 & $\begin{array}{l}\text { Large product choice of goods for appear- } \\
\text { ance and health }\end{array}$ & 25 & 27 & 12 \\
\hline 1.4 & $\begin{array}{l}\text { Presence of novelties in the commodity } \\
\text { class for appearance and health }\end{array}$ & 19 & 33 & 12 \\
\hline 1.5 & Possibility to buy an exclusive product & 17 & 31 & 16 \\
\hline 2 & Presence of pharmacy brand & 32 & 27 & 5 \\
\hline 3 & Presence of pharmacy open form of trade & 36 & 26 & 2 \\
\hline 4 & $\begin{array}{l}\text { Formatting of fronts, pharmacies sale- } \\
\text { srooms }\end{array}$ & 42 & 12 & 10 \\
\hline 5 & Pharmacy competent personnel, possibility & 61 & 3 & 1 \\
\hline
\end{tabular}




\begin{tabular}{|c|c|c|c|c|}
\hline & to obtain profconsultation & & & \\
\hline 6 & $\begin{array}{l}\text { Possibility to obtain complementary servic- } \\
\text { es: order of infrequent medications, home- } \\
\text { delivery service, medservices directly in a } \\
\text { pharmacy, special diagnostic centers in the } \\
\text { sphere of beauty, private zones, anthropo- } \\
\text { logical measurings, lease of orthopedic } \\
\text { products, phyto-café and etc. }\end{array}$ & 37 & 14 & 13 \\
\hline 7 & $\begin{array}{l}\text { Not only medication can be bought in a } \\
\text { pharmacy }\end{array}$ & 32 & 17 & 15 \\
\hline 8 & $\begin{array}{l}\text { Prolonged working hours (or twenty-four- } \\
\text { hour) }\end{array}$ & 53 & 3 & 8 \\
\hline 9 & $\begin{array}{l}\text { The pharmacy has some additional testi- } \\
\text { monies about work quality (for instance, } \\
\text { quality certificate posted in a salesroom) }\end{array}$ & 36 & 24 & 4 \\
\hline \multirow[t]{2}{*}{10} & $\begin{array}{l}\text { Systems for consumers attracting act in the } \\
\text { pharmacy: discount cards, discount sys- } \\
\text { tems, promo-actions of producers of medi- } \\
\text { cations and medical equipment, presents }\end{array}$ & 36 & 20 & 8 \\
\hline & Choice criteria & Yes & No & Sometimes \\
\hline 11 & $\begin{array}{l}\text { Network and individual pharmacies are dis- } \\
\text { tinguished }\end{array}$ & 34 & 27 & 3 \\
\hline 12 & $\begin{array}{l}\text { Readiness to pay extra money for queues } \\
\text { absence }\end{array}$ & 16 & 38 & 10 \\
\hline 13 & $\begin{array}{l}\text { Readiness to pay extra money for the high } \\
\text { service level in a pharmacy }\end{array}$ & 20 & 39 & 5 \\
\hline 14 & $\begin{array}{l}\text { Readiness to overcome significant dis- } \\
\text { tance for low prices on medications }\end{array}$ & 17 & 25 & 22 \\
\hline
\end{tabular}

*Source:comprised on the basis of 150 employees quiz of North-Ossetian state university of K.L. Khetagurov

Key advantages, which provide strong brend for a pharmacy are considered.

1.Strong brend is a possibility to profitably emphasize a pharmacy on the general phone, give it originality, and endow it with characteristics important for customers. To estimate the brend strength, one should educe the conformity of three constituents to the desired image in the customers' consciousness:

- brend image - its emotionally colored image, formed in consumers' consciousness and capable to influence on their behavior. Image designation - to create and maintain proper impression about pharmacy;

- associations, which emerge, when people get acquainted with a pharmacy. "The right" associations point to specialization, atmosphere, organization targeted audience and etc.;

- individuality - description of brend in terms, which we use for a person description. The "right" individuality representseither a typical customer, with whom it is easily to be identified, or a person, to whom one strives to be similar with.

2. The more famous the brend, the more accurate expectations are formulated from the pharmacy visiting. In the result the strong brend presupposes responsibility of pharmacy for summary quality parameters of the given goods and service system. This responsibility (quality guarantees, service level and etc.) attracts the customers and allows correcting the prices with benefit for the pharmacy. 
3. Extra value, offered by the brend, leads to the fact that the consumers are initially prepared to pay higher price for the goods, and also easier bear advance in prices.

If the title of a pharmacy is easy to remember, and the brend possesses stable positive characteristics, then people begin to come habitually to the pharmacy.

4. The strong brend helps to "create" loyal customers cohort for the pharmacy i.e. those clients, who under the other various conditions choose our pharmacy, and they also actively recommend the pharmacy to those friends and familiar people. The strong brend acts as one of the most important loyalty guarantees to the pharmacy, as brings to the customer additional meaning and value of his visit.

The loyalty program appears to be the important influencing factor the consumer behaviour.

Loyaltyis a response positive reaction to the firm's efforts. If a customer begins to feel as a part of pharmacy, begins to oversee its development, be interested in its success and plans - a person experiences loyalty to thepharmacy. Rational and emotional factors should be collocated in the program of loyalty development and support. From the rational point of view special preferences/peculiar conditions should be planned. From the "emotion" position it is necessary to emphasize customer unique character and its importance, belonging to the society of "special" people, who are appreciated and understood and that the pharmacy prosperity depends on it.

Under the conditions of serious competition, pharmaceutical institutions have to resort to various means of attracting and retention of the customers. Traditional set of acceptable prices, assortmentwidth, high quality pharmaceutics, cosmeceutics and medical production, and also convenient location of the pharmacy and pharmaceutical goodslaying out are considered to be priority factors in the context of consumers' loyalty cultivation and preservation. However, for the moment these are obligatory, but not sufficient attributes of the consumers' adherence to the concrete pharmacy. Recently pharmacies began to fight for the customers with other methods - through discounts giving to the customers, mainly to the constant consumers, and, generally, with the help of discount cards. Though the easier variants are also possible: for instance, there is 3-5\% discount for all customers at the weekend and holidays, or there are exclusive discounts for separate medications, which are given to customers during promotion actions conducting. The manager of a pharmacy or pharmaceutical network defines population category for discount providing, depending on the group kind he places stake on, whom he wants to attract.

However, discount cards possess considerably bigger marketing potential. Anyway, discount cards in pharmaceutical networkact not only to attract the customers, but solve a whole row of other important functional challenges.Particularly, the analysis of targeted audience can be conducted with the help of them, as discount cards are issued after special questionary filling.

Discount programs are considered to be the often case of loyalty programs organization. The key marketing peculiarities of pharmaceutical purchases for the majority of consumers are:

- episodic (the average customer makes about 25-30 of purchases in a year), besides the significant part of these purchases is unpredictable (in connection with unchronic diseases);

- small sizes of majority of purchases;

- significant price difference on $95 \%$ of pharmaceutical goods (within 600 rub.), which comprises in a big city dozens of percents(in Moscow usually about 30-50 \% relating to average urban price, in Vladikavkaz - 10-15\%) [1,p. 16].

That is why for majority of customers the convenient location of a pharmacy and/or the base level of price (under the more expensive purchases), hesitating in dozens of per- 
cent in a big city, is more significant than discount (which by convention should be lower than pure profitability, i.e., in majority of cases cannot exceed 5-7\%) [1,p.17].

However, the loyalty programs are not created only on the basis of discount policy or prices manipulation. The customers' loyalty cannot be bought. It should be earned. Consequently, the main values should be nonmaterial and expressed in a special level of service and attention. The consulting assistance, rendering customers can serve as an example.First of all some commercialization of medical services and significant queues to a qualified doctorpush commercial pharmaceutical sector to an active consulting role. In the result many patients often resort to dispensers for consulting assistance on treatment of rather wide diseases spectrum, even without trying to consult a doctor. Sometimes consultations organization of attracted bypharmacies doctors in the hall or area of pharmacy appears to be economically effective "answer" on such population demands. However, as the practice shows, this is justified only in those rare cases, when a doctor possesses a talent in relation to purchase stimulation. Usually expenses on a doctor-consultant exceed economical effect from his consultations.

That is why generally passable pharmacies, relating to networks, realize the consumers consulting. The experience of consulting projects shows that effective work of dispensers with customers is capable to increase the volume of commercial market approximately on $10-15 \%$ [2,p. 43].Offer of substitute or supplementary medications are considered to be the other directions of consulting. Thus, the great number of synonymous/analogs, differed in price and profitability in times(and sometimes in order) are presented in many popular assortment groups. This creates a significant potential of price increase of purchase and pharmacy turnover under the competent, flexible work of dispensers with customers. Initiative recommendationsjustify themselves: offer of more modern analogues, "supplementary"goods - vitamins, bracing medications, probiotics together withantibiotics purchase and etc.

Thus, before initiate the loyalty program development, it is necessary to find out, how far the customers are satisfied with the pharmacy work. If the client is not fully satisfied with it, then loyalty program will not be priority. Evidently that in such situation it is necessary to obtain the other measures and try to change something in the pharmacy activity. Loyalty is based on satisfaction feeling. Consequently, one should avoid situations of so called "false loyalty". Complexity consists in the fact that often one takes frequent visit of the pharmacy and conclude purchases by a customer as loyalty manifestation. But the real reasons for this may not have a direct relationship to loyalty. For instance:

- there is noalternative (a pharmacy is one in the region);

- there is noessential difference between neighboring pharmacies(why should it be changed?);

- risk avoidance (the place is tested - the goods are qualitative);

- the pharmacy offers solution of all problems, though not in the best way (many customers prefer the pharmacy, where besides the medications one can buy also the goods for children, and cosmetics, and foodstuff even at higher prices, then visit many points);

- the pharmacy offer better financial conditions for purchase (accumulative discounts and other special offers can for some time neutralize presence of better alternatives).

Using of considered influence instruments to the pharmaceutical production consumers behavior that requires reforming of dispensers extended education, will allow to high, from one side, the level of economical activity of pharmaceutical operators, from the other -satisfaction of medications consumers[8].

The integration questions of retail personnel and producers, considered earlier, branding and loyalty programs, in our opinion, can be referred to the client-oriented pharmacy network program. 
Small forms of pharmacies, including in rural area, within the framework of researched marketing instruments can use merchandising, control for assortment and customers competent service. For instance, the most topical problems, connected with customers service and contact establishment, for one of the private pharmacy of bedroom community of Vladikavkaz are turned to be:

- knowledge insufficiency of goods from positions "characyeristics- advantage- benefit";

- absence of behavior experience with dissatisfied customers;

- inefficiency to conduct express-analysis of accomplished sale.

However, in our opinion, under the conditions of pharmacies network development in the region, from one side, and necessity of alternative pharmaceutical enterprises functioning, from the other side, priority marketing instrument for the mentioned forms of pharmaceuticalretail should be emphasized. Herewith, the common, in our opinion, is the use of "attract-function" technology by all types of pharmacy, which consists of three main components:

- service constituent - accessibility of curative assistance, quality guarantee, catalogue of provided services and etc.;

- aesthetic constituent - pharmacyinterior decoration, appearance of personnel, design of suggested goods for realizations and etc.;

- ethical constituent - relation to the clients and work skills. The main condition for client-oriented approach formation -a necessity to develop and find the balance between the all three components of "attract-function".

\section{Лumepamypa}

1. Ким Д. Факторы долгосрочного успеха аптеки // Российские аптеки. 2013. №2.

2. Дзагоева А.P.Особенности аптечного мерчандайзинга и его взаимосвязь с потребительским поведением в аптеке // Российское предпринимательство. 2008. № 7 Вып. 2 (115).

3. Gurieva L.K., Zangiev I.E., Dzatseev D.R. Moral aspects of liberal economy formation in russia // Гуманитарныеисоциально-экономическиенауки. 2016. № 1 (86).

4. Gurieva L.K. New strategic approach to the innovative development of regions // НаучныйальманахстранПричерноморья. 2016. № 2 (6).

5. Gurieva L.K., Dzhioev A.V. Sustainable development of the russian economy // HaучныйальманахстранПричерноморья. 2016. № 2 (6).

6. Kamalova O.N., Andramonova V.V.Networksociety: problemsofdevelopmentandnewformsofidentity // Актуальные проблемы науки: от теории к практике Материалы III Всероссийской научно-практической конференции. 2016.

7. Kolosova O.Y., Goncharov V. N.Economic and ecological safety of the region: strategy choice // НаучныйальманахстранПричерноморья. 2015. № 3. http://science-almanac.ru

8. Nadtochy Y.V., Klochko E.N., Danilina M.V., Gurieva L.K., Bazhenov R.I., Bakharev $V . V$. Economic factors and conditions for the transformation of the education services market in the context of globalization//International Review of Management and Marketing. 2016. T. 6. № S1. 
9. KimD. The factors of long-term success of pharmacy // Russian pharmacies. 2013. No2.

10. DzagoevaA.R. Peculiarities ofpharmaceutical merchandising and its interconnection with consumer behavior in pharmacy // Russianentrepreneurship. -2008 . - No 7 Issue. 2 (115).

11. Gurieva L.K., Zangiev I.E., Dzatseev D.R. Moral aspects of liberal economy formation in Russia // Humanitarianuand socioeconomic sciences. 2016. No 1 (86).

12. Gurieva L.K. New strategic approach to the innovative development of regions // Science almanac of Black sea region countries. 2016. No 2 (6).

13. Gurieva L.K., Dzhioev A.V. Sustainable development of the Russian economy // Science almanac of Black sea region countries. 2016. No 2 (6).

14. Kamalova O.N., Andramonova V.V.Network society: problems of development and new forms of identity // Topical problems of science: from theory to practice the Materials of III All-Russian scientific-practical conference. 2016.

15. Kolosova O.Y., Goncharov V. N.Economic and ecological safety of the region: strategy choice // Science almanac of Black sea region countries. 2015. No 3. http://science-almanac.ru

16. Nadtochy Y.V., Klochko E.N., Danilina M.V., Gurieva L.K., Bazhenov R.I., Bakharev $V . V$. Economic factors and conditions for the transformation of the education services market in the context of globalization//International Review of Management and Marketing. 2016. T. 6. No S1.

March, 3, 2017 